\title{
Enzyme assisted extraction of chitin from shrimp shells (Litopenaeus vannamei)
}

Article

Accepted Version

Hongkulsup, C., Khutoryanskiy, V. and Niranjan, K. (2016) Enzyme assisted extraction of chitin from shrimp shells (Litopenaeus vannamei). Journal of Chemical Technology and Biotechnology, 91 (5). pp. 1250-1256. ISSN 0268-2575 doi: https://doi.org/10.1002/jctb.4714 Available at https://centaur.reading.ac.uk/43511/

It is advisable to refer to the publisher's version if you intend to cite from the work. See Guidance on citing.

To link to this article DOI: http://dx.doi.org/10.1002/jctb.4714

Publisher: Wiley

All outputs in CentAUR are protected by Intellectual Property Rights law, including copyright law. Copyright and IPR is retained by the creators or other copyright holders. Terms and conditions for use of this material are defined in the End User Agreement.

\section{www.reading.ac.uk/centaur}

\section{CentAUR}

Central Archive at the University of Reading 
Reading's research outputs online 
2 Choosit Hongkulsup ${ }^{a *}$, Vitaliy V. Khutoryanskiy ${ }^{b}$ and Keshavan Niranjan ${ }^{a}$

3

* Correspondence to: Choosit Hongkulsup, Department of Food and Nutritional Sciences, University of Reading, Reading RG66AP, United Kingdom.E-mail: zg023439@reading.ac.uk

${ }^{a}$ Department of Food and Nutritional Sciences, University of Reading, Reading RG6 6AP, United Kingdom.

${ }^{b}$ Reading School of Pharmacy, University of Reading, Reading RG6 6AD, United Kingdom.

\section{Abstract}

BACKGROUND: Chemical chitin extraction generates large amounts of wastes and increases partial deacetylation of the product. Therefore, the use of biological methods for chitin extraction is an interesting alternative. The effects of process conditions on enzyme assisted extraction of chitin from the shrimp shells in a systematic way were the focal points of this study.

RESULTS: Demineralisation conditions of $25^{\circ} \mathrm{C}, 20 \mathrm{~min}$, shells-lactic acid ratio of 1:1.1 w/w; and shellsacetic acid ratio of 1:1.2 w/w, the maximum demineralisation values were 98.64 and $97.57 \%$ for lactic and acetic acids, respectively. A total protein removal efficiency of $91.10 \%$ by protease from Streptomyces griseus with enzyme-substrate ratio $55 \mathrm{U} / \mathrm{g}, \mathrm{pH} 7.0$ and incubation time $3 \mathrm{~h}$ is obtained when the particle size range is $50-25 \mu \mathrm{m}$, which was identified as the most critical factor. The X-ray diffraction and ${ }^{13} \mathrm{C}$ NMR spectroscopy analysis showed that the lower percent crystallinity and higher degree of acetylation of chitin from enzyme assisted extraction may exhibit better solubility properties and less depolymerisation in comparison with chitin from the chemical extraction.

CONCLUSION: The present work investigates the effects of individual factors on process yields, and it has shown that, if the particle size is properly controlled a reaction time of $3 \mathrm{~h}$ is more than enough for deproteination by protease. Physicochemical analysis indicated that the enzyme assisted production of chitin seems appropriate to extract chitin, possibly retaining its native structure.

Keywords: Chitin; Protease; demineralisation; deproteination; characterisation

\section{Introduction}

White leg shrimp (Litopenaeus vannamei) is one of the most commercially exploited shrimp species in Asia and the Americas, which also generates a large amount of shrimp bio-waste. The global annual production of shell waste from crustacean harvest is estimated to 3.14 million metric tons dry weight. ${ }^{1}$ Currently shrimp waste is used as a supplement in animal feed or simply discarded; however, it is an important source of chitin $^{2}$, which happens to be the second most abundant natural 
polysaccharide after cellulose isolated from shells of crustaceans, insects and cell walls of fungi. This polymer is a linear beta 1,4-linked polymer of N-acetyl-D-glucosamine (GlcNAc) and further deacetylated to produce chitosan and its derivatives. ${ }^{3}$ Usually, chitin is bound to proteins, calcium carbonate, lipids, and pigments in exoskeleton..$^{4,5}$

The production of chitin from shellfish waste consists of three steps: deproteination, demineralisation, and decolorisation. ${ }^{6}$ Owing to covalent associations with other shell components, industrial methods for chitin and chitosan isolation from different crustacean shells usually rely on harsh chemical techniques. In the chemical process, the shellfish is treated with hydrochloric acid in order to remove calcium carbonate. ${ }^{7}$ Generally, a strong alkali treatment (sodium hydroxide) is used to remove proteins as well as other organic impurities. These procedures generate large amounts of chemical wastes and increase partial deacetylation of chitin as well as hydrolysis of the polysaccharide, resulting in inconsistent properties of the final products. ${ }^{8,9}$

Some studies on the use of proteases from bacterial isolates for the deproteination of shellfish wastes have been reported. Bustos and Michael ${ }^{10}$ used a protease from Pseudomonas maltophilia for deproteination without alkali. The deproteination of crustacean shell reached to about $64 \%$ after incubation for 6 days. Additionally, it has been reported that a bacterial protease from Bacillus sp. TKU004 could be employed under optimized conditions in 2\% slurry of squid pen powder. ${ }^{11}$ The extent of deproteination was found to be $63 \%$ after 2 days and peaked at $73 \%$ after 3 days. Proteolytic protease from Streptomyces griseus is a mixture of exo- and endo-proteases and contains at least ten proteolytic components, which therefore has very broad specificity, cleaving nearly all peptide bonds, and is used in cases where extensive or complete degradation of protein is required. ${ }^{12,13}$

However, the levels of residual protein and the reaction time for the biological process are excessively high which, combined with higher costs compared to the chemical method, limit process applicability on an industrial scale. ${ }^{14}$ The improvement of biological processes to produce chitin and its derivatives is therefore necessary. Thus, despite its promising potential, limited information exists within the published scientific literature on a biological extraction method; particularly how one could make biological process for chitosan manufacture a competing alternative to the chemical method.

This experimental study aims to demonstrate the potential of enzyme assisted methods for chitin production from shrimp shell waste in a systematic way. The effects of process conditions, such as incubation time and enzyme-substrate ratio and particle size of substrate, on the deproteination and demineralisation of shrimp shell waste are evaluated, with the aim of increasing the efficiency and yields of this method. Moreover, the physicochemical properties of chitin isolated by enzyme assisted 
1 production were investigated using solid-state ${ }^{13} \mathrm{C}$ nuclear magnetic resonance $\left({ }^{13} \mathrm{C} \mathrm{NMR}\right)$ spectroscopy,

2 X-ray diffraction (XRD), and scanning electron microscopy (SEM).

3

4 5

\section{Materials and Methods}

\section{Materials}

White leg shrimp shells (Litopenaeus vannamei) obtained from Kingfisher holding Ltd., Thailand, were initially treated with hot tap water to remove foreign materials and then dried in an oven at $60^{\circ} \mathrm{C}$. Washed and dried shells were ground to powder in a blender. Commercial protease from Streptomyces griseus (EC no. 232-909-5, Sigma Aldrich) with a declared activity of $5.5 \mathrm{U} / \mathrm{mg}$ was used under the following conditions: $\mathrm{pH}$ between $5.0-9.0$ and temperature between $20-40^{\circ} \mathrm{C} .{ }^{13}$

\section{Chemical analysis of the raw materials}

The moisture and ash contents were analysed at $105^{\circ} \mathrm{C}$ and $550^{\circ} \mathrm{C}$, respectively, in accordance with the AOAC standard methods 930.15 and $942.05 .{ }^{15}$ Total nitrogen content of each raw material was analysed by using the Kjeldahl method. Separately, for each raw sample, pure chitin was prepared to measure its nitrogen content, allowing to determine the crude protein content by multiplying nitrogen content attributed to protein by the factor of $6.25 .{ }^{16}$ Lipids were analysed gravimetrically by soxhlet extraction using hexane.

\section{Demineralisation by organic acid}

\section{Effect of incubation time on demineralisation}

Deproteinised shells were treated with $0.5 \mathrm{M}$ lactic and $0.5 \mathrm{M}$ acetic acid at a solid: acid ratio of $1: 0.7 \mathrm{w} / \mathrm{w},{ }^{17}$ and placed on a magnetic stirrer platform at $25^{\circ} \mathrm{C}$ for $10,20,40$ and $60 \mathrm{~min}$. The pellet was washed with distilled water until the sample was neutral and then dried at $60^{\circ} \mathrm{C}$.

Effect of substrate-acid ratio on demineralisation

Based on the results of the experiment described in the previous section, a time of 20 min was chosen to evaluate the effect of substrate-acid ratio on demineralisation, with $0.5 \mathrm{M}$ lactic and $0.5 \mathrm{M}$ acetic acids at ratios of 1:0.5, 1:0.7, 1:0.9, 1:1.0, 1:1.1, 1:1.2 and 1:1.4 w/w. The samples were then stirred for $20 \mathrm{~min}$ at $25^{\circ} \mathrm{C}$ and stored for analysis and deproteination. The degree of demineralisation (DDM) was showed as a percentage and calculated by the following equation ${ }^{18}$ :

$$
\% D D M=\frac{\left\{\left(A_{o} \times O\right)-\left(A_{R} \times R\right)\right\}}{A_{o} \times O} \times 100
$$


where $A_{O}$ and $A_{R}$ are ash contents (\%) before and after demineralisation respectively, while $O$ and $R$ represent the mass $(\mathrm{g})$ of initial and demineralized residue respectively on dry weight basis.

\section{Deproteination by protease}

\section{Effect of incubation time}

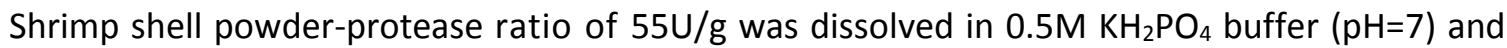
incubated at $37^{\circ} \mathrm{C}$ for $10,30,60,120,180,300$ and $600 \mathrm{~min}$. Subsequently, the reaction was stopped by placing the mixture in a $90^{\circ} \mathrm{C}$ water bath for $30 \mathrm{~min}$. This was followed by centrifugation, and washing the pellet with distilled water until the sample had neutral $\mathrm{pH}$ 7.0. The pellet was washed with $99 \%$ ethanol to remove unwanted colour and then dried at $60^{\circ} \mathrm{C}$, whereby the sample was kept for analysis.

\section{Effect of enzyme-substrate $(E / S)$ ratio}

Based on the results of the experiment described in the previous section, a time of $180 \mathrm{~min}$ was chosen to evaluate the effect of enzyme-substrate ratio on the degree of deproteination, with shrimp

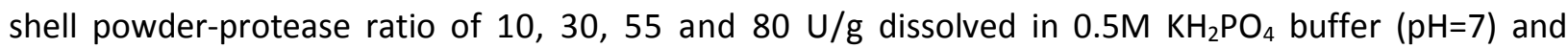
incubated at $37^{\circ} \mathrm{C}$.

Effect of $\mathrm{pH}$

Based on the results of the previous experiment, a time of $180 \mathrm{~min}$ and enzyme-substrate (E/S) ratio of $55 \mathrm{U} / \mathrm{g}$ were chosen to evaluate the effect of $\mathrm{pH}$ on the degree of deproteination, with $0.5 \mathrm{M}$ $\mathrm{KH}_{2} \mathrm{PO}_{4}$ buffer in a $\mathrm{pH}$ range varying from 4.0 to 9.0 and incubated at $37^{\circ} \mathrm{C}$.

Effect of particle size

Holding the incubation time of $180 \mathrm{~min}$, an enzyme-substrate ratio of $55 \mathrm{U} / \mathrm{g}$, temperature of $37^{\circ} \mathrm{C}$ and $\mathrm{pH}=7$, the effect of particle size on the rate of deproteination was determined by selecting the following sieved fractions: $300-212,212-105,105-50$ and $50-25$ and $<25 \mu \mathrm{m}$. The larger particle sizes were expected to give lower reaction rates and were not considered. The degree of deproteination (DDP) was showed as percentage and calculated by the following equation ${ }^{18}$ :

$$
\% D D P=\frac{\left\{\left(P_{o} \times O\right)-\left(P_{R} \times R\right)\right\}}{P_{o} \times O} \times 100
$$

where $P_{O}$ and $P_{R}$ are the protein concentrations (\%) before and after hydrolysis respectively, while $O$ and $\mathrm{R}$ represent the mass $(\mathrm{g})$ of original sample and hydrolysed residue respectively on dry weight basis.

\section{Chemical extraction of chitin.}


The same shrimp shell powders were demineralised with $1 \mathrm{M} \mathrm{HCl}$ in the ratio $1: 15(\mathrm{w} / \mathrm{v})$ at $35^{\circ} \mathrm{C}$ for $12 \mathrm{~h}$. The demineralised shells were then deproteinised with $1 \mathrm{M} \mathrm{NaOH}$ solution in the ratio 1:10 $(\mathrm{w} / \mathrm{v})$ at $35^{\circ} \mathrm{C}$ for $24 \mathrm{~h}$. Crude chitin was obtained after washing until the filtrate was neutral.

\section{Physicochemical characterisation of chitins}

Solid-state ${ }^{13} \mathrm{C}$ NMR spectroscopic

The NMR spectra of chitin were carried out by the CP-MAS ${ }^{13} \mathrm{C}$ NMR method (crosspolarization/magic-angle-spinning) using a BRUKER Avance III $500 \mathrm{MHz}$ (BRUKER, Germany). NMR spectra of chitin were indexed at a ${ }^{13} \mathrm{C}$ frequency of $75.5 \mathrm{MHz}$. CP-MAS technique was used with the following conditions: $5 \mathrm{~s}$ of ${ }^{13} \mathrm{C}$ spin lattice relaxation time; $8 \mathrm{~ms}$ of contact time; and $8 \mathrm{kHz}$ of a spinning rate. ${ }^{19}$ The degree of acetylation (DA) of chitin was computed from the relative intensities of the resonance of the ring carbon $\left(\mathrm{I}_{\mathrm{C}_{1},}, \mathrm{I}_{\mathrm{C} 2}, \mathrm{I}_{\mathrm{C}_{3},}, \mathrm{I}_{\mathrm{C} 4}, \mathrm{I}_{\mathrm{C}}, \mathrm{I}_{\mathrm{C} 6}\right)$ and methyl carbon $\left(\mathrm{I}_{\mathrm{CH}_{3}}\right)$ obtained from ${ }^{13} \mathrm{C} \mathrm{NMR}$ patterns by the following equation ${ }^{20}$ :

$$
\% D A=\frac{I_{C H 3}}{\left(I_{c 1}+I_{c 2}+I_{c 3}+I_{c 4}+I_{c 5}+I_{c 6}\right) / 6} \times 100
$$

X-ray diffraction (XRD)

$X$-ray diffraction measurements were used to analyse the crystallinity of the samples and their spectra were indexed using a D8 advance XRD (Bruker, Germany) with CuK $\alpha$ radiation $(\lambda=1.5406)$. Based on the XRD analysis, the $2 \theta$ angle was scanned from $5^{\circ}$ to $45^{\circ}$ and the counting time was $2.0 \mathrm{~s}$ with an angle step width of $0.05^{\circ}$. The crystallinity index $(\% \mathrm{Crl})$ was determined as shown in the following Equation. $^{21}$

$$
\% C r l=\frac{\left(I_{110}-I_{a m}\right)}{I_{110}} \times 100
$$

where $I_{110}$ is the maximum intensity at $2 \theta \cong 20^{\circ}$ and $I_{a m}$ is the intensity of amorphous diffraction at $2 \theta \cong 16^{\circ}$.

\section{Scanning electron microscopy (SEM)}

SEM (Cambridge 360 Stereoscan, UK) was applied to determine the surface characteristics of chitin at 3000x magnification. The samples were fixed on a sample holder, dried by a critical point dryer, and coated with a thin gold layer of $3 \mathrm{~nm}$ by a sputter coater for conductivity.

\section{RESULTS AND DISCUSSION}

\section{Proximate composition of shrimp shells powder}


Chitin was extracted from white leg shrimp (Litopenaeus vannamei) shells. The chemical compositions of the raw materials were determined following methods described above. The results obtained are given in Table 1. It is evident from the table that the values given compare favourably with the normal values for protein and ash content reported by Rodde et $a .^{22}$ For analysing particle-size distribution, ground shrimp shell was sieved by test sieves at different sieve mesh between 300, 212, 105,50 and $<25 \mu \mathrm{m}$. The predominant fraction of ground shrimp shells ranged between $212-105 \mu \mathrm{m}$, and this fraction was used as the starting material.

\section{Demineralisation}

The percentage demineralisation represents the removal of inorganic mineral, mostly calcium carbonate, from shrimp shell. It is clear from Fig. 1 that the percentage demineralisation increased with time up to $20 \mathrm{~min}$ to reach a maximum value of $73.85 \%$ and $65.66 \%$ in the case of lactic and acetic acids respectively, beyond which it remains constant. The greater percentage demineralisation achieved with lactic acid than acetic acid at the same shell-acid ratio and reaction time, is probably because lactic acid $\left(\mathrm{pK}_{\mathrm{a}}=3.86\right)$ is a stronger acid than acetic acid $\left(\mathrm{pK}_{\mathrm{a}}=4.76\right)$. In demineralisation of chitin, the reaction time is an important factor since extended reaction times increase the cost and also affect the properties of the purified chitin. ${ }^{17}$ It is obvious from Fig. 1 that, with a stoichiometrically adequate amount of acid, the demineralisation reaches a maximum value within $20 \mathrm{~min}$. Any excess contact time can potentially degrade chitin properties.

Fig. 2 indicates that \% demineralisation increased significantly when the shells-acid ratio was increased. When shells-lactic acid ratio was 1:1.1 w/w, almost complete demineralisation was observed (98.64\%). While shells-acetic acid ratio was $1: 1.2 \mathrm{w} / \mathrm{w}$, total minerals removal efficiency was $97.57 \%$. Mahmoud et al. ${ }^{17}$ investigated the demineralisation of shrimp shells by organic acids and reported that the effectiveness of lactic acid in removing the minerals from the shells was higher than acetic acid. Under the conditions: shells-acid ratio of $1: 20$, temperature of $24{ }^{\circ} \mathrm{C}$ and incubation time of $2 \mathrm{~h}$, the percentage demineralisation achieved were $\mathbf{9 7 . 4 \%}$ and $\mathbf{8 6 . 3 6 \%}$ for lactic and acetic acids, respectively. The presence of stoichiometrically adequate amount of acid (regardless of type) is a pre-requisite for the complete removal of minerals $s^{6,23}$ and any excess used only increases the production costs and has an adverse environmental impact.

\section{Deproteination}

The extent of deproteination is defined as the percentage of protein removed from shrimp shell powder (dry weight). A significant percentage of deproteination occurs in the first $30 \mathrm{~min}$, and it increases gradually with incubation time up to around $300 \mathrm{~min}$, and then it levels off at a value just over 
$82.07 \%$ (Fig. 3). The reason for the extent of deproteination levelling off may be due to a combination of factors. It is quite possible that with the loss of proteins and other solubles, the number of active sites for the enzyme to adsorb may have reached a limit. Further, the enzyme may also be unable to access the protein substrate remaining, because of the lower concentration and the entrapment of the protein in a calcium rich matrix. ${ }^{5}$ This indicates that the maximum possible substrate has been used up for a given particle size. ${ }^{24,25}$ This hypothesis also suggests that the extent of deproteination can be altered by changing the particle size, which will be shown to be the case in the following section. Since there is no significant change in the protein content after $180 \mathrm{~min}$, an incubation time of $3 \mathrm{~h}$ was deemed to be suitable in the further experiments. It is interesting to note that earlier workers in this area have used a much longer incubation time of 24 h or even greater, ${ }^{10,11,26}$ which is really not necessary.

Fig. 4 suggests that \% deproteination increases with the increase in enzyme-substrate ratio from 10 to $55 \mathrm{U} / \mathrm{g}$, beyond which there is no further increase in the \% deproteination which remains at $58.61 \%$. Shi et $a .^{25}$ has made a similar observation working with nuclease and DEAE cellulose, and observed that immobilized enzyme activity increased with the increase of enzyme content. However, once the binding sites on the surface of DEAE cellulose were saturated, immobilized enzyme activity cannot be increased by an increase of enzyme content. In this study, the enzyme-substrate ratio of 55 U/g of shrimp shell powder seems appropriate for further studies.

To determine the effects of optimum $\mathrm{pH}$ on the deproteination of shrimp shells waste, the initial $\mathrm{pH}$ values have been kept in the range of 4.0-9.0 by the addition of $1 \mathrm{M} \mathrm{NaOH}$, and the results are shown in Fig. 5. The optimum pH was around 7.0 under these conditions and the proteolytic activities decreased over $\mathrm{pH}=8$. Protease from Streptomyces griseus has optimal activity at $\mathrm{pH}=7.0-8.0$. However, individual components are mentioned to retain activity over a much wider $\mathrm{pH}$ range $(\mathrm{pH}=5.0-9.0)$, which is due to the differences in substrates, buffer solutions, and reaction time. ${ }^{13}$

The effect of particle size range on \% deproteination is shown in Fig. 6 . The \% deproteination increases as the particle size decreases and a maximum value of $91.10 \%$ is obtained when the particle size range is $50-25 \mu \mathrm{m}$. The particle size of the substrates can influence mass transfer of the substrates to contact with the enzymes, and subsequently influence the enzyme-catalysed activity. ${ }^{27}$ Therefore, the substrates with finer particles showed an improvement in enzyme-catalysed activity due to an increase in surface area. ${ }^{28}$ This is also in agreement with the report of Meyer, ${ }^{29}$ who stated that enzyme activity increases with increasing surface area/volume ratio, showing the importance of exposed surface area on the starch hydrolysis reaction. 
However, a further decrease in the particle size $(<25 \mu \mathrm{m})$ did not bring about a significant difference in \% deproteination. The use of particles smaller than $25 \mu \mathrm{m}$ had no further increase in $\%$ deproteination, which may be attributed to these fine particles forming a more viscous dispersion. There are other explanations for this effect reported in literature. Munawar et al. ${ }^{30}$ suggested that the lower conversion was due to overlapping of the particles which masks some of the active sites. Petnamsin et al. $^{31}$ also revealed that the finer particles of milled starch granule lost their crystalline regions, and tended to form clumps during blending process. This may result in a decrease in surface area of substrates which decreased the enzyme-catalysed activity. It is important to note that \% deproteination as high as $91.10 \%$ obtained in just $3 \mathrm{~h}$ was significantly better than many other proteases reported in previous studies. ${ }^{10,11,26,32}$ This is because these authors have not controlled the particle size and used the values which are much higher than the values used in this work.

\section{Characterisation of chitin}

The crystalline structures of the chitins from enzyme assisted extraction and chemical extraction were characterized by x-ray powder diffraction (Fig. 7). It was found that five crystalline peaks were observed in the $2 \theta$ range of $5-50^{\circ}$ and were recorded as $020,110,120,101$ and 130 corresponding to $\alpha-$ chitin structure. ${ }^{33}$ The x-ray diffraction patterns of the chitin from chemical extraction showed higher intense peak areas than the chitin from protease-lactic and from protease-acetic extraction, which indicated that the chitin from chemical extraction had higher crystallinity. ${ }^{34}$

In this study, the crystallinity index of the chitin from chemical extraction, protease-lactic and from protease-acetic extraction were $89.12 \%, 82.56 \%$ and $80.64 \%$, respectively (Table 2 ). It was found that, the lower percent crystallinity of chitin obtained by enzyme assisted production may exhibit higher solubility properties in comparison with chitin produced from the chemical production, owing to the more severe process conditions during the chemical method. ${ }^{35}$ Thus, the enzyme assisted production of chitin under mild conditions seems appropriate to prevent the degradation and partial depolymerisation of native chitin.

Solid state ${ }^{13} \mathrm{C}$ NMR spectroscopy is a reliable technique to analyse the differences in polysaccharide composition and structure, allowing a direct measurement of the degree of acetylation. ${ }^{36}$ Fig. 8 shows ${ }^{13} \mathrm{C}$ NMR data of chitins obtained from chemical extraction, protease-lactic and protease-acetic extraction. The spectrum consisted of eight well-defined signals, including C1-C6 carbons of $\mathrm{N}$-acetyl glucosamine monomers were detected between 50 and 110 ppm. The methyl group of the acetyl group was around 23 ppm, while the carbonyl group generated a peak at around 173 ppm. The ${ }^{13} \mathrm{C}$ NMR signals of $\mathrm{C}-3$ (73 ppm) and C-5 (75 ppm) were obviously isolated into two peaks, corresponding to the typical of $\alpha$-chitin structure. ${ }^{37}$ Degree of acetylation (DA) of chitin prepared by 
chemical extraction, protease-lactic and protease-acetic extraction were $81.47 \%, 90.83 \%$ and $92.67 \%$, respectively (Table 2). It was showed that DA of the two chitins isolated by enzyme assisted extraction was higher than that of chitin obtained by chemical extraction. Observed differences in the DA values could be attributed to the partial deacetylation of polymer occurring in the chemical treatment. The severity of demineralisation and deproteination conditions affects the possible degradation of the polymer leading to inconsistent physicochemical properties in the purified chitin. ${ }^{32}$ Hence, the enzyme assisted production of chitin is a promising alternative method to extract chitin, possibly retaining a native structure of chitin.

Fig. 9 shows the SEM images of chitin from chemical extraction (A), chitin from protease-lactic extraction (B), and chitin from protease-acetic extraction. The SEM image of chitin from chemical extraction displayed a tightly packed morphology, while the surface of two chitins from enzyme assisted extraction showed less density and slightly microfibrillar structure (Fig. 9B and 9C), which may result from the higher crystallinity index of chitin from chemical extraction method.

\section{CONCLUSION}

Effective demineralisation conditions of $25^{\circ} \mathrm{C}, 20 \mathrm{~min}$, shells-lactic acid ratio of $1: 1.1 \mathrm{w} / \mathrm{w}$; and shells-acetic acid ratio of 1:1.2 w/w, the maximum demineralisation values were 98.64 and $97.57 \%$ for lactic and acetic acids, respectively. A total protein removal efficiency of $91.10 \%$ with enzyme-substrate ratio $55 \mathrm{U} / \mathrm{g}$ and incubation time $3 \mathrm{~h}$ is obtained when the particle size range is $50-25 \mu \mathrm{m}$, which is a major improvement over earlier studies. The present work represents a systematic attempt to investigate the effects of individual factors on process yields, and it has shown that, if the particle size is properly controlled a reaction time of $3 \mathrm{~h}$ is more than enough - which makes the biological process for chitin manufacture a competing alternative to the chemical method. The XRD and ${ }^{13} \mathrm{C} N M R$ analysis indicated that the enzyme assisted production of chitin is a promising alternative method to extract chitin, possibly retaining a native structure of chitin. Of course, further research work is needed, that takes a holistic view of deproteination and demineralisation, to result in a robust biological method for chitin manufacture.

\section{Acknowledgements}

The authors are grateful to the Chemical Analysis Facility (CAF) in the Department of Chemistry, University of Reading for the use of the NMR, XRD and SEM. Particular thanks go to: Dr. Radoslaw M. Kowalczyk, Mr. Nick Spencer, and Dr. Peter Harris. 


\section{References}

21 Venugopal V, Marine Polysaccharides: Food Applications. CRC Press, 396 p (2011).

32 No HK, Meyers SP and Lee KS, Isolation and characterization of chitin from crawfish shell waste. J Agric Food Chem 37(3):575-579 (1989).

3 Alishahi A and Aïder M, Applications of chitosan in the seafood industry and aquaculture: A review. Food Bioprocess Tech 5:817-830 (2012).

4 Luquet $\mathrm{G}$, Testeniere $\mathrm{O}$ and Graf F, Characterization and N-terminal sequencing of a calcium binding protein from the calcareous concretion organic matrix of the terrestrial crustacean Orchestia cavimana. Biochim Biophys Acta, 1293:272-276 (1996).

5 Hild S, Marti O and Ziegler A, Spatial distribution of calcite and amorphous calcium carbonate in the cuticle of the terrestrial Crustaceans Porcellio scaber and Armadillidium vulgare. J Struct Biol 163:100-108 (2008).

6 Shahidi F and Synowiecki J, Isolation and characterization of nutrients and value-added products from snow crab (Chionoecetes opilio) and shrimp (Pandalus borealis) processing discards. J Agric Food Chem 39:1527-1532 (1991).

7 Khor E, Chitin: Fulfilling a Biomaterials Promise. Elsevier Applied Science, Amsterdam, the Netherlands, 148 p (2001).

8 Andrade VS, Neto BB, Fukushima K and Campos-Takaki GM, Effect of medium Components and time of cultivation on Chitin production by Mucor circinelloides (Mucor javanicus IFO 4570)-A factorial study. Rev Iberoam Micol 20:149153 (2003).

9 Kim SK and Mendis E, Bioactive compounds from marine processing by products-A review. Food Res Int 39:383-393 (2006).

10 Bustos RO and Michael H, Microbial deproteinisation of waste prawn shell, in Institution of Chemical Engineers Symposium Series, Institution of Chemical Engineers, Rugby, UK, pp 13-15 (1994).

11 Wang SL, Lin TY, Yen YH, Liao HF and Chen YJ, Bioconversion of shellfish chitin wastes for the production of Bacillus subtilis W-118 chitinase. Carbohydr Res 341(15):2507-2515 (2006).

12 Nomoto M, Narahashi Y and Murakami M, A proteolytic enzyme of Streptomyces griseus. Hydrolysis of protein by Streptomyces griseus protease. J Biochem 48(4):593-602 (1960).

13 Narahashi Y, Shibuya K and Yanagita M, Studies on proteolytic enzymes (Pronase) of Streptomyces griseus K-1. Separation of exo- and endopeptidases of Pronase. J Biochem 64(4):427-437 (1968).

14 Percot A, Viton C and Domard A, Optimization of chitin extraction from shrimp shells. Biomacromolecules 4:12-18 (2003).

15 AOAC, Official Methods of Analysis of Association of Official Analytical Chemists (12th Ed.). AOAC, Washington, DC (1975).

16 Tshinyangu KK, Hennebert GL, Protein and chitin nitrogen contents and protein content in Pleurotus ostreatus var. columbinus. Food Chem 57:223-227 (1996).

17 Mahmoud NS, Ghaly AE and Arab F, Unconventional Approach for Demineralisation of Deproteinized Crustacean Shells for Chitin Production. Am J Biochem Biotechnol 3(1):1-9 (2007).

18 Rao MS, Munoz J and Stevens WF, Critical factors in chitin production by fermentation of shrimp biowaste. Appl Microbiol Biotechnol 54:808-813 (2000).

19 Ghorbel-Bellaaj O, Hmidet N, Jellouli K, Younes I, Maâlej H, Hachicha R and Nasri M, Shrimp waste fermentation with Pseudomonas aeruginosa A2: Optimization of chitin extraction conditions through Plackett-Burman and response surface methodology approaches. Int J Biol Macromol 48(4):596-602 (2011).

20 Ottoy MH, Varum KM and Smidsord O, Compositional heterogeneity of heterogeneously deacetylated chitosans.

21 Ghorbel-Bellaaj O, Jellouli K, Younes I, Manni L, Salem MO and Nasri M, A solvent-stable metalloprotease produced by 
22 Rodde RH, Einbu A, Vårum KM, A seasonal study of the chemical composition and chitin quality of shrimp shells obtained from northern shrimp (Pandalus borealis). Carbohydr Polym 71(3):388-393 (2008).

23 Synowiecki J and Al-Khateeb NA, Production, properties and some new applications of chitin and its derivatives. Crit Rev Food Sci Nutr 43:145-171 (2003).

24 Tucker GA and Woods LFJ, Enzymes in Food Processing Second Edition. Blackie Academic \& Professional, Glasgow, $319 \mathrm{p}$ (1995).

25 Shi LE, Yi Y, Tang ZX, Xiong WY, Mei JF and Ying GQ, Nuclease p1 immobilized on DEAE cellulose. Braz J Chem Eng 27(1):31-39 (2010).

26 Oh KT, Kim YJ, Nguyen VN, Jung WJ and Park RD, Demineralisation of crab shell waste by Pseudomonas aeruginosa F722. Process Biochem 42:1069-1074 (2007).

27 Yu HW, Chen H, Wang X, Yang YY and Ching CB, Cross-linked enzyme aggregates (CLEAs) with controlled particles: Application to Candida rugosa lipase. J Mol Catal B: Enzym 43:124-127 (2006).

28 Molony AP, O'Rorke A, Considine PJ and Coughlan MP, Enzymatic saccharification of sugar beet pulp. Biotechnol Bioeng 26:714-718 (1984).

29 Meyer NL, Effect of Immobilization Method on Activity of Alpha-Amylase. Department of Food, Agricultural, and Biological Engineering. The Ohio State University (2007).

30 Munawar TM, Swamy AVN, Lakshmi GR, Murthy CVR and Rao DM, Studies on production of cellulase from Antigonum Leptopus leaves using Trichoderma reesei (NCIM 1186) under solid-state fermentation conditions. Int J Pharm Res Dev 3(7):193-200 (2011).

31 Petnamsin C, Termvejsayanon N and Sriroth K, Effect of Particle Size on Physical Properties and Biodegradability of Cassava Starch/Polymer Blend. Kasetsart J (Nat Sci) 34:254-261 (2000).

32 Younes I, Hajjia S, Frachetb V, Rinaudoc M, Jelloulia K and Nasri M, Chitin extraction from shrimp shell using enzymatic treatment. Antitumor, antioxidant and antimicrobial activities of chitosan. Int J Biol Macromol 69:489-498 (2014).

33 Wada M and Saito YJ, Lateral thermal expansion of chitin crystals. J Polym Sci, Part B: Polym Phys 39:168-174 (2001).

34 Sajomsang W and Gonil P, Preparation and characterization of $\alpha$-chitin from cicada sloughs. Mater Sci Eng, C 30:357-363

35 Tolaimate A, Desbrieres J, Rhazi A, Vincendon M and Vottero P, On the influence of deacetylation process on the physicochemical characteristics of chitosan from squid chitin. Polymer 41:2463-2469 (2000).

36 Van de Velde $K$ and Kiekens $P$, Structure analysis and degree of substitution of chitin, chitosan and dibutyryl chitin by FT-IR spectroscopy and solid state ${ }^{13} \mathrm{C}$ NMR. Carbohydr Polym 58:409-416 (2004).

37 Cárdenas G, Cabrera G, Taboada E, and Miranda SP, Chitin characterization by SEM, FTIR, XRD, and ${ }^{13} \mathrm{C}$ cross polarization/mass angle spinning NMR. J Appl Polym Sci 93:1876-1885 (2004). 


\section{Tables}

3 Table 1 Proximate composition on \% dry basis of ground shrimp shell; the remaining represents the 4 percentage of chitin.

\begin{tabular}{cc}
\hline Composition & Amount (\%) \\
\hline Protein & $28.40 \pm 0.58$ \\
Ash & $47.66 \pm 0.61$ \\
Moisture & $4.69 \pm 0.07$ \\
Lipid & $0.82 \pm 0.04$ \\
\hline
\end{tabular}

5

6 Table 2 Degree of acetylation (DA) and crystallinity index ( $\mathrm{Crl}$ ) of chitin obtained by chemical extraction, 7 protease-lactic and by protease-acetic extraction

\begin{tabular}{l|c|c}
\hline \multicolumn{1}{c|}{ Samples } & DA (\%) & Crl (\%) \\
\hline Chitin obtained by chemical extraction & $81.47 \pm 0.70$ & $89.12 \pm 0.65$ \\
Chitin obtained by protease-lactic & $90.83 \pm 0.85$ & $82.56 \pm 0.92$ \\
Chitin obtained by protease-acetic & $92.67 \pm 0.61$ & $80.64 \pm 1.03$ \\
\hline
\end{tabular}

8

9

\section{Graphs}

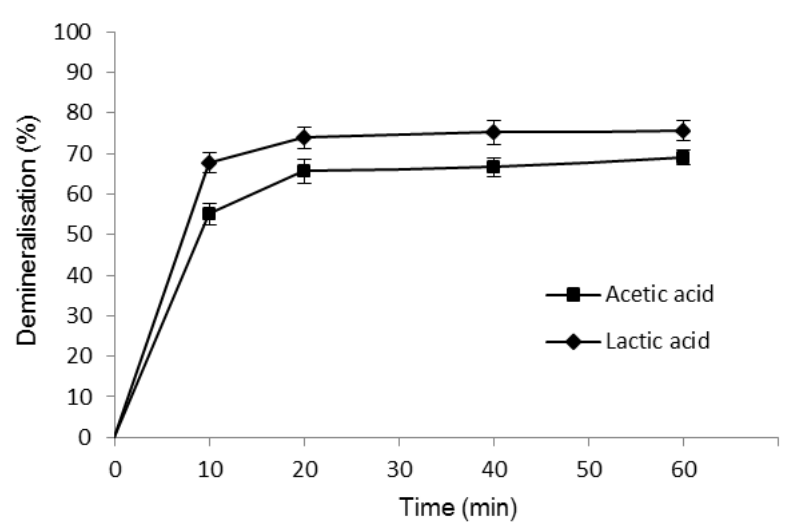

12

13 Figure 1. Effect of incubation time on demineralisation. Incubation conditions: $0.5 \mathrm{M}$ lactic and acetic 14 acids; shells-acid ratio $=1: 0.7 \mathrm{w} / \mathrm{w}$; temperature $=25^{\circ} \mathrm{C}$. 


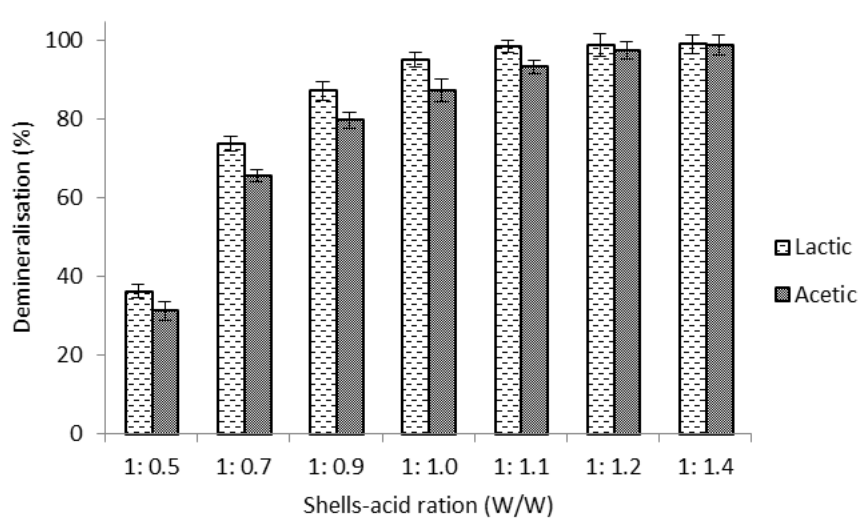

1

Figure 2. Effect of shrimp shell-acid ratio on demineralisation. Incubation conditions: $0.5 \mathrm{M}$ lactic and 3 acetic acids; temperature $=25^{\circ} \mathrm{C}$; incubation time $=20 \mathrm{~min}$.

4

5

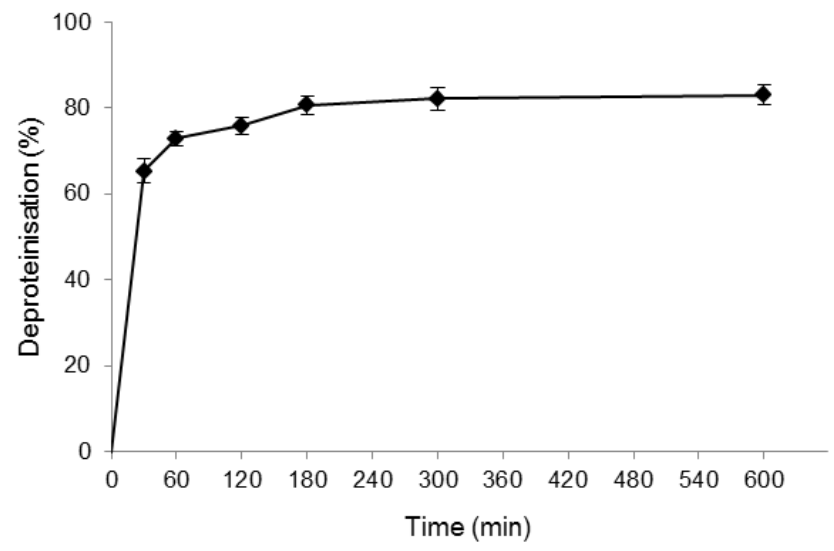

6 Figure 3. Effect of incubation time on the rate of deproteination. Incubation conditions: protease 7 activity $=55 \mathrm{U} / \mathrm{g}$; solid liquid ratio $=1: 25 ; \mathrm{pH}=7$; temperature $=37^{\circ} \mathrm{C}$; particle size range $=212-105 \mu \mathrm{m}$.

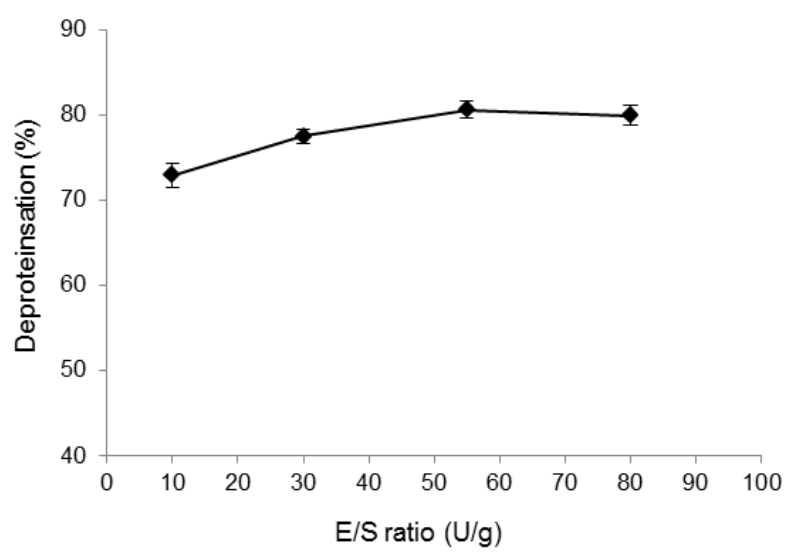

10 Figure 4. Effect of enzyme-substrate ratio on the degree of deproteination. Incubation conditions: solid 11 liquid ratio $=1: 25 ; \mathrm{pH}=7$; temperature $=37^{\circ} \mathrm{C} ;$ particle size range $=212-105 \mu \mathrm{m}$; incubation time $=3 \mathrm{~h}$. 
1

2 Figure 5. Effect of $\mathrm{pH}$ on the degree of deproteination. Incubation conditions: protease activity $=55 \mathrm{U} / \mathrm{g}$;

\begin{abstract}
solid-liquid ratio $=1: 25$; temperature $=37^{\circ} \mathrm{C} ;$ particle size range $=212-105 \mu \mathrm{m} ;$ incubation time $=3 \mathrm{~h}$.
\end{abstract}
4

8

8
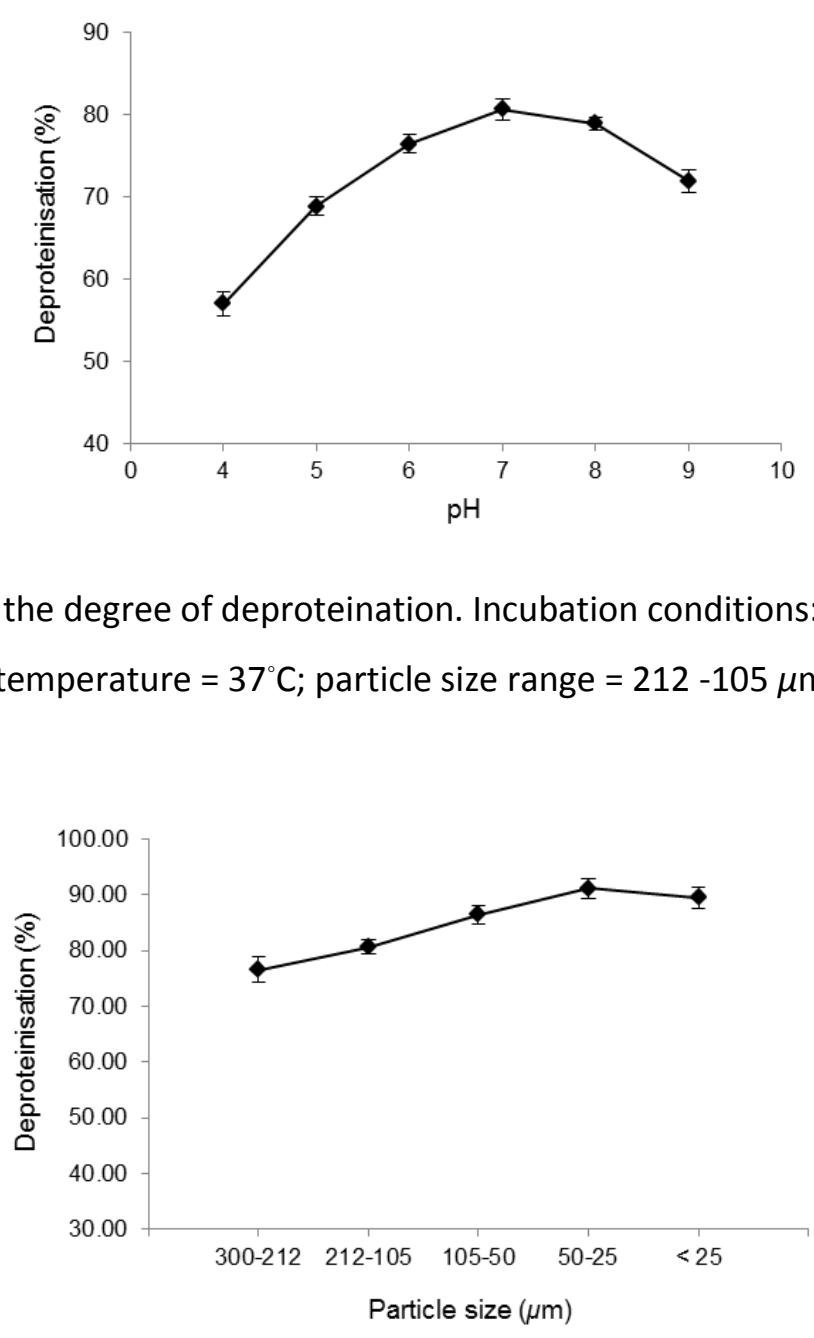

Figure 6. Effect of particle size of shrimp shell powder on deproteination. Incubation conditions: protease activity $=55 \mathrm{U} / \mathrm{g}$; solid-liquid ratio $=1: 25 ; \mathrm{pH}=7$; temperature $=37^{\circ} \mathrm{C}$; incubation time $=3 \mathrm{~h}$.

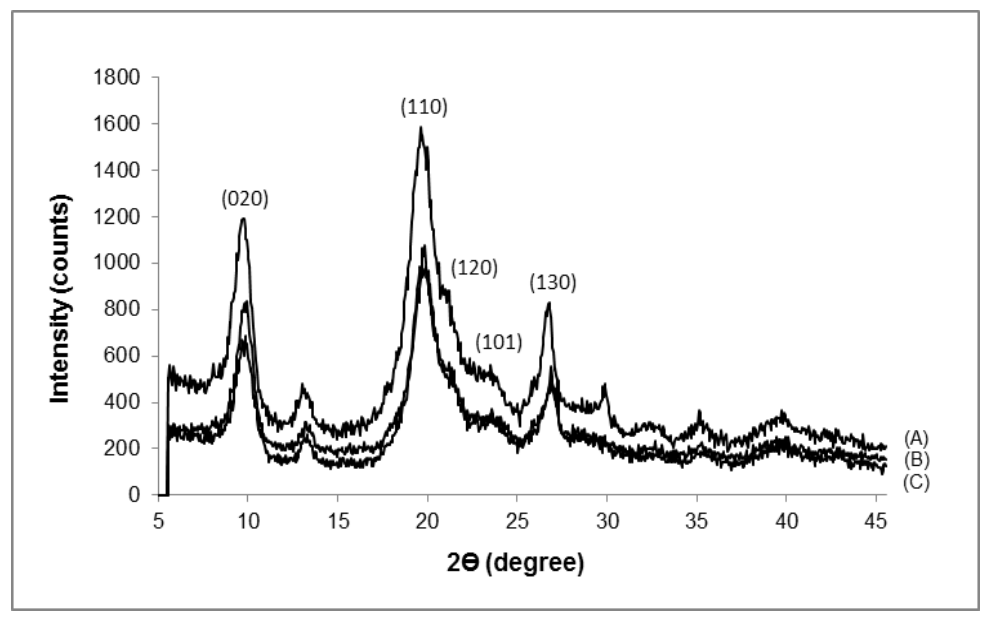

10 Figure 7. X-ray diffraction patterns of chitin from chemical extraction (A), chitin from protease-lactic production (B), and chitin from protease-acetic production (C). 
7 Figure 8. ${ }^{13} \mathrm{CP} / \mathrm{MAS}$ NMR spectrum of chitin from chemical (A) chitin from protease-lactic production (B), 4

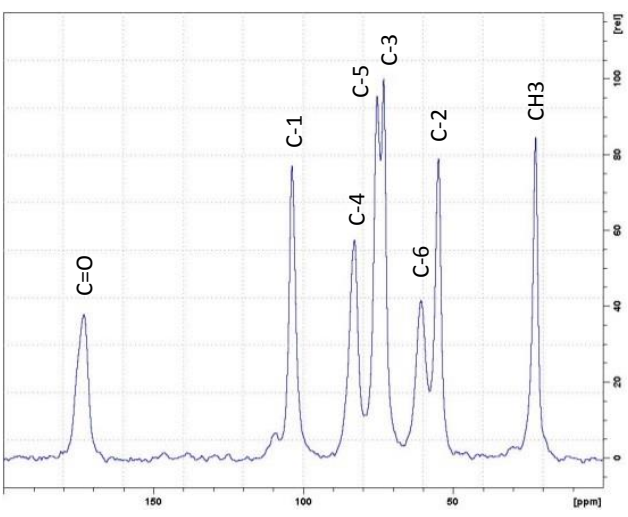

(C) chitin from protease-acetic production

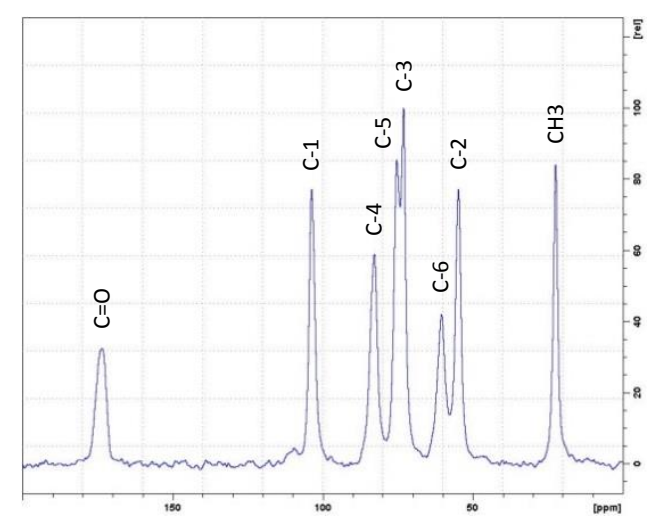

(A) chitin from chemical extraction

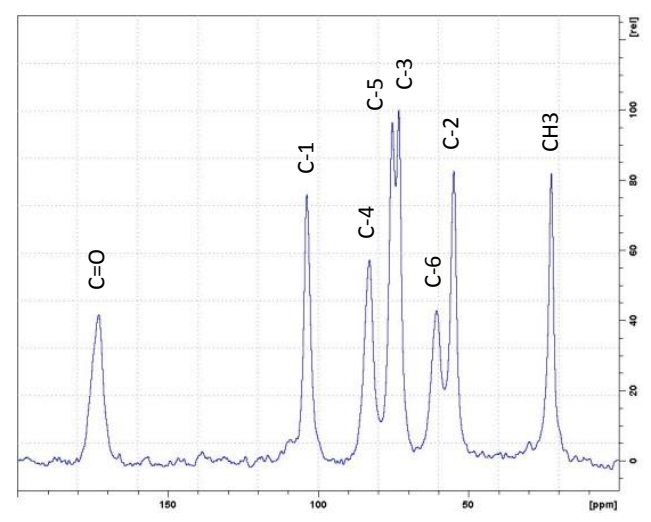

(B) chitin from protease-lactic production

8 and chitin from protease-acetic production (C).

\section{Pictures}

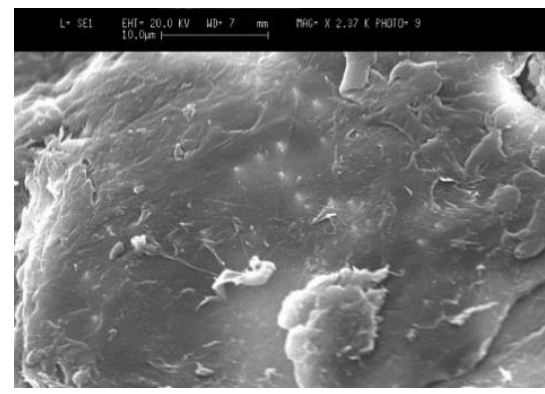

(A)

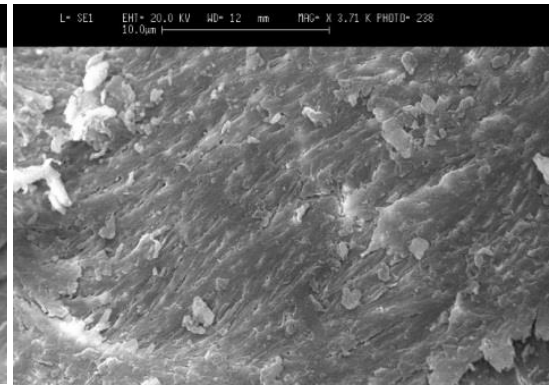

(B)

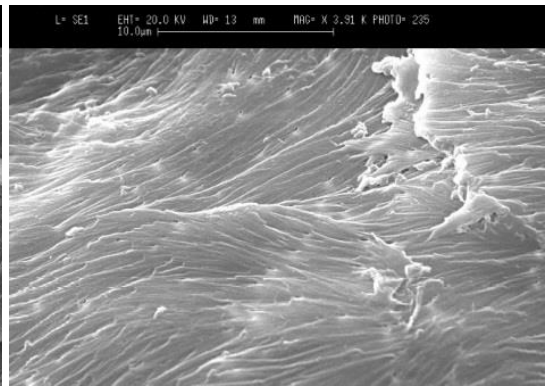

(C)

Figure 9. SEM images of chitin from chemical (A), chitin from protease-lactic production (B), and chitin from protease-acetic production (C). 